\title{
UTILIZING ICT TO DEVELOP STUDENT'S LANGUAGE ETHIC AT ISLAMIC UNIVERSITY
}

\author{
Eka Apriani \\ Institut Agama Islam Negeri Curup, Indonesia \\ Email: ekaapriani_90@ymail.com

\section{Dadan Supardan} \\ Universitas Islam Negeri Mataram, Indonesia \\ Email: dadan_65@ymail.com
}

Eka Sartika

Universitas Islam Negeri Raden Fatah Palembang, Indonesia

Email: ekasartika_uin@radenfatah.ac.id

\section{Suparjo}

Institut Agama Islam Negeri Purwokerto, Indonesia

Email: suparjohusain73@gmail.com

Ihsan Nul Hakim

Institut Agama Islam Negeri Curup, Indonesia

Email: sanulki_74@yahoo.com

\begin{abstract}
ICT is tools or medias that facilitate teaching and learning process in the classroom. ICT includes software application, computers, radio, television, telephony, CD ROM, audio or video clips, computer, and internet. Utilizing this technology is not improve students' achievement but also their character, especially language ethic. Students' language ethic has relationship to linguistics aspects. In semantics, the study tells about how polite language used to communicate with other people in the real context. In pragmatics, the study tells about how polite language used to communicate with older and younger people based on the situation. There were some words and expressions can be used and can be not used to communicate with other people. One way to teach semantics and pragmatics was used ICT in the calssroom. Using ICT that input Islamic value can develop the students' character indirectly. Hopefully, all of the English lecturer using ICT as English teaching media at Islamic university.
\end{abstract}

Keywords: ICT, Islamic university, language ethic

\begin{abstract}
Abstrak
TIK adalah alat atau media yang memfasilitasi proses belajar mengajar di kelas. TIK meliputi aplikasi perangkat lunak, komputer, radio, televisi, telepon, CD ROM, klip audio atau video, komputer, dan internet. Memanfaatkan teknologi ini tidak meningkatkan prestasi siswa tetapi
\end{abstract}


Eka Apriani, Dadan Supardan, Eka Sartika, Suparjo, Ihsan Nul Hakim: Utilizing ICT to Develop Student's Language Ethic at Islamic University

juga karakter mereka, terutama etika bahasa. Etika bahasa siswa memiliki hubungan dengan aspek linguistik. Dalam semantik, penelitian ini menceritakan tentang bagaimana bahasa sopan digunakan untuk berkomunikasi dengan orang lain dalam konteks nyata. Dalam pragmatik, penelitian ini menceritakan tentang bagaimana bahasa sopan digunakan untuk berkomunikasi dengan orang yang lebih tua dan lebih muda berdasarkan situasi. Ada beberapa kata dan ungkapan yang bisa digunakan dan tidak bisa digunakan untuk berkomunikasi dengan orang lain. Salah satu cara untuk mengajarkan semantik dan pragmatik adalah menggunakan TIK di ruang calss. Menggunakan TIK yang memasukkan nilai islami dapat mengembangkan karakter siswa secara tidak langsung. Semoga semua dosen Bahasa Inggris menggunakan TIK sebagai media pengajaran bahasa Inggris di perguruan tinggi Islam.

Kata Kunci: etika bahasa, TIK, universitas Islam

\section{A. Introduction}

In Law Number 20 of 2003, article (3) states that national education functions to develop the capabilities and shape of dignified national character and civilization in order to educate the life of the nation, aiming to develop the potential of students to become faithful and devoted to God, righteous noble, healthy, knowledgeable, capable, creative, independent, democratic and responsible citizen. ${ }^{1}$

In addition, the Ministry of National Education describes the character education objectives that are expected by the Ministry of National Education to consist of 5 (five) aspects. First, the objective is developing the potential of the heart/conscience/affective of students as human being and citizen who have cultural values and national characters. Second, the objective is developing the habits and behavior of students who are commendable and appropriate with universal values and religious traditions of the nation's cultures. Third, the objective is instilling the spirit of leadership and responsibility of students as the next generation of the nation. Fourth, the objective is developing the ability of students to become independent, creative, nationalistic people. Fifth, the objective is developing the school's living environment as a safe, honest learning environment, full of creativity and friendship, and with a high sense of nationality and dignity. ${ }^{2}$

\footnotetext{
${ }^{1}$ Kementerian Pendidikan Nasional, Sistem Pendidikan Nasional, Retrieved 08 Minggu, 2018, from http://kelembagaan.ristekdikti.go.id:http://kelembagaan.ristekdikti.go.id/wp-content/uploads/2016/ 08/UU_no_20_th_2003.pdf

${ }^{2}$ Kementerian Pendidikan Nasional, Pengembangan Pendidikan Budaya dan Karakter Bangsa. (Jakarta: Badan Penelitian dan Pengembangan Pusat Kurikulum, 2010), 9
} 
In other words, Zubaedi states that character education has three main functions. First, the function is the formation and development of potential. Character education form and develop students' potential to be good-minded, kind-hearted, and behave in accordance with the philosophy of Pancasila. Second, repairing and strengthening functions. Character education improves and strengthens the role of families, education units, communities, and the government to participate and be responsible for developing the potential of citizen and nation building towards an advanced, independent and prosperous nation. Third, filter function. Character education separates its own national culture and filters the culture of other nations that are not in accordance with the values of the nation's cultural values and dignified national characters. ${ }^{3}$

One type of character that is very closeto the community is politeness or language ethics. Decency or language ethics are closely related to language because language is a reflection of someone's attitude and behavior. According to Pantu \& Luneto, language is a symbol of human existence. ${ }^{4}$ From the language, someone can know their desires, their educational background, their customs, even their home regions or countries. There is a phrase "language shows the nation". Language is a culture that is owned by each group or nation. Language reflects the ethics, attitude, and memory of education that is owned by someone. The Ministry of National Education also states that language has a central role in the intellectual, social, and emotional development of students and is a supporting success in learning all fields of study. Language learning is expected to help students get to know themselves, their culture, and other people's culture, express the language, and find and use analytical and imaginative abilities that exist in themselves. ${ }^{5}$

One of the ways to develop students' language ethic is using ICT in teaching and learning process. Technology is not only can improve students' motivation and ability but also their characters. Language ethic is one of a good character which important aspect for them to be a future leader and also to collaborate with each other in their society. ${ }^{6}$

\footnotetext{
${ }^{3}$ Zubaedi, Desain Pendidikan Karakter Konsepsi dan Apliaksinya dalam Lembaga Pendidikan (Jakarta: Prenada Media Gorup, 2011), 18

${ }^{4}$ A. Pantu \& H. Luneto, Pendidikan Karakter dan Bahasa, Al-Ulum 14 (01), 2014: 155.

${ }^{5}$ Departemen Pendidikan Nasional, Standar Isi Kurikulum Mata Pelajaran Bahasa Indonesia (Jakarta: Depdiknas, 2006), 44

"Eka Apriani, "A New Literacy: The Role of ICT to develop Student's Character," Ta'dib: Journal of Islamic Education 21 (1) 2016: 59.
} 
ICT is not only improving the students' character but also can decrease their morality. In addition, the teacher should be monitor and control their students' activity when they are using ICT in the classroom. One of the negative effects using internets is pornography.

Pornography is very dangerous for students since it can decrease students' morality. For this condition, teachers become an important person who have significant roles in avoiding the pornography affects the students. The teachers have authority to control and monitors students' activity, at least at school, where students spend most of their time. ${ }^{7}$

So, it can be said that ICT has positive and negative impact for the students. Negative impact will be prevent if the students having a good character. ICT has important role in improving students' characters. The writer will discuss more about the positive impact of ICT to improve students Islamic characters in Islamic university. This paper explains more about: 1) What kinds of ICT used to develop students character?; 2) How can ICT develop students' character?; and 3) Why language ethic is important for the students?; 4) What are the relationship between language ethic toward semantics and pragmatic study?;5) How can ICT develop students' character in semantic and pragmatics study?.

\section{B. ICT}

ICT is a technology which stands for Information and Communication Technologies. ICT as diverse set of technological tools and resources used to communicate, create, disseminate, store, and manage information. ${ }^{8}$ This technology is very helpful for the teacher because it does not only deliver the contents, but also to construct knowledge and meaning. ${ }^{9}$

ICT as a set of tools enabling, supporting, and reinforcing educational reform. ${ }^{10}$ Occasionally, the State of Queensland, 2002 postulated that ICTs are at the core of teaching and learning in the 21st Century. Queensland's futuredepends on how successfully we integrate ICTs in the curriculum and daily learning and teaching. Many

\footnotetext{
${ }^{7}$ Eka Apriani, "The Misuse of ICT by Students: The Effect of Phornography and the Teacher Solutions," Tadrib: Jurnal Pendidikan Agama Islam, 2015: 1.

${ }^{8}$ L.V. Tinio, ICT in Education, (New York: Stephen Brwon Group, 2002).

${ }^{9} \mathrm{C}$. Vrasidas \& McIsaac, Integrating Technology in Teaching and Teacher Education, 2001. Retrieved August Monday, 13, from http://www.tandf.co.uk/journals

${ }^{10}$ N. C. Alexander, M. Mar, \& D. McCalman, "Information and Communication Technolgies (ICT): Components Dimensions and Its Ccorrelates,” JITIM 24 (4) 2015.
} 
teachers already use computers to enliven teaching and inspire students. ${ }^{11}$ In addition states that ICT includes computers, broadcasting technologies (radio and television), telephony, CD ROM, audio or video clips, computer, and internet. ${ }^{12}$ The most common technology used by people are computer and internet.

\section{Students' Characters}

According to the language (etymology) the character word comes from Latin Kharakter, kharassein, and kharax. In Greek the character comes from or charassein, which means "make sharp" and "make in." In English it is called character and in Indonesian it becomes karakter. According to the Big Indonesian Dictionary, the character is interpreted as psychological traits that distinguish one person from another.

Understanding the character refers to "moral" understanding which has the following explanation, according to Arabic etymology, morals are a form of jam '(plural) of "khuluq" which is an infinitive form of the word khalaqa - yakhluqu - khuluqan which means temperament (al-sajiyah), basic behavior, character (al-thabi'ah); custom (al-'adat), good civilization (al-muru'ah), and religion (al-din). The word "morality" hasmeaning, temperament, habits, even religion but is not found in the Qur'an, which is found is only a single form of the word that is khuluq. ${ }^{13}$

In addition, Zuhriyah said that character education is the same as ethics education (moral). The purpose of character (morals) is to develop the character or behavior of students by way of living up to the values of public beliefs as a moral strengh of life through honesty, trustworthiness, and cooperation that emphasizes the effective domain (feeling, attitude) without leaving the cognitive domain (thinking rational) and psychomotor domains (skills, skilled data processing, expressing opinions and cooperation). And a person can be said to have a character if he has successfully absorbed the values and beliefs that society wants and used as a strength in his life. ${ }^{14}$

${ }^{11}$ C. M. Zuppo, "Defining ICT in a Boundaryless World: The Development of a Working Hierarchy," International Journal of Managing Information Technology 4 (3) 2012.

${ }^{12}$ C. D. Diem, Perpustakaan, Kepustakaan dan Keaksaraan (Palembang: PT. Rambang, 2011), $87-90$

${ }^{13}$ Quraisy Shihab, Tafsir Al-Mishbah: Pesan, Kesan dan Keserasian Al-Qur'an, Vol. 13 (Jakarta: Lentera Hati, 2002), 56

${ }^{14}$ Heni Zuhriyah, Pendidikan Karakter (Studi Perbandingan Antara Konsep Koesoema dan Ibnu Miskawaih (Surabaya: IAIN Sunan Ampel, 2010), 37 
According to the Ministry of Education and Culture of the Republic of Indonesia there are five main character values derived from Pancasila, which are the priorities for the development of the KDP movement; namely religious, nationalism, integrity, independence and mutual cooperation. ${ }^{15}$ Each value does not stand up and develop individually, but interacts with each other, develops dynamically and forms personal integrity.

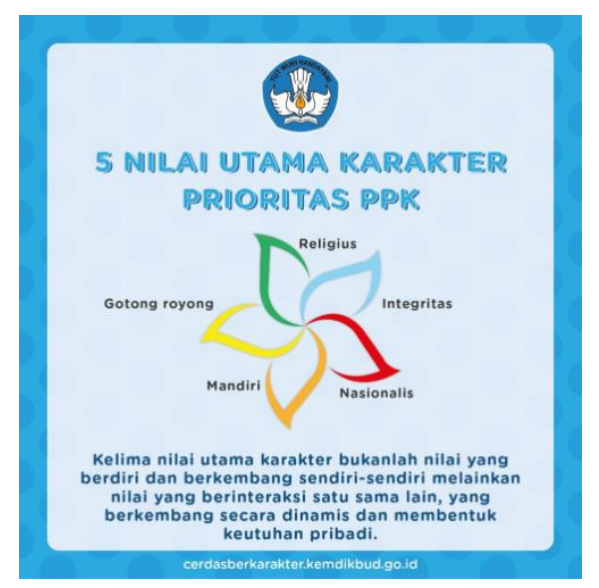

Picture 1. Main Values of Character

First, the value of "religious" character reflects faith in God Almighty which is manifested in the behavior of carrying out religious teachings and beliefs that are embraced, respecting religious differences, upholding tolerant attitudes toward religious practices and other beliefs, living in harmony and peace with followers of other religions. The implementation of the value of religious character is shown in an attitude of peace, tolerance, respect for differences in religion and belief, firm conviction, confidence, cooperation between adherents of religion and belief, anti-abuse and violence, friendship, sincerity, not imposing the will, loving the environment, protecting the poor people and marginalized.

Secondly, the value of "nationalist" character is a way of thinking, acting, and acting that shows high loyalty, concern, and appreciation for the language, physical environment, social, cultural, economic and political nation, placing the interests of the nation and state above their self and group interests. Nationalist attitudes are demonstrated through an attitude of appreciation for the nation's own culture,

\footnotetext{
${ }^{15}$ Kementerian Pendidikan dan Kebudayaan, Penguatan Pendidikan Karakter Jadi Pintu Masuk Pembenahan Pendidikan Nasional. Retrieved 08 Minggu, 2018, from www.kemdikbud.go.id: https://www.kemdikbud.go.id/main/blog/2017/07/penguatan-pendidikan-karakter-jadi-pintu-masukpembenahan-pendidikan-nasional
} 
safeguarding the wealth of the nation's culture, willing to sacrifice, excel, love the motherland, protect the environment, obey the law, discipline, respect the diversity of culture, ethnicity and religion.

Third, the value of the character of "integrity" is the value that underlies behavior based on the effort to make himself as a person who can always be trusted in words, actions, and work, has a commitment and loyalty to human and moral values. The character of integrity includes the attitude of responsibility as citizens, actively involved in social life, through consistency of actions and words based on truth. A person with integrity also respects the dignity of individuals (especially persons with disabilities), and is able to demonstrate exemplary behavior.

Fourth, the value of "independent" character is the attitude and behavior that does not depend on others and uses all the energy, mind, time to realize the hopes, dreams and ideals. Independent students have a good, strong, fighting, professional, creative, courageous, and lifelong work ethic.

Fifth, the value of the character of "mutual cooperation" reflects the act of respecting the spirit of cooperation and working together to solve common problems, establish communication and friendship, provide assistance to people in need. It is hoped that students can show respect for others, can work together, be inclusive, be able to commit to joint decisions, consensus, help, have empathy and a sense of solidarity, anti-discrimination, anti-violence, and volunteerism.

From the five values of the main characters above, which will be discussed in full about the value of religious characters. One of the values of religious character is mutual respect between fellow human beings both to older people and to fellow peers. indicators of mutual respect between fellow human beings that is using polite language ethics when communicating. The ethics of the language used must be distinguished according to the situation and partner in conversation.

\section{Utilizing ICT to develop Students' Character}

Technology has a pivotal role in teachers and students' practices such as promoting collaborative learning,improving communication skills, enhancing teachers and students' motivation through diverse activities and updated information as well as increasing learners achievement due to the reinforcement and various practices provided 
in the Internet. ICT is not only promoting and improving students' motivation but also students' characters. The Urban Programs Resource Network, in providing resources for educators through the University of Illinois Extension Program, reinforced the value of character education:

Character education is the development of knowledge, skills, and abilities that enable the learner to make informed and responsible choices ...Character education enables students to come face to face with the realities of life. It encourages them to think critically and then act responsibly. Instructional materials, methods and strategies, when developed into interdisciplinary curricular themes, empowers teachers to create meaning while allowing students time for purposeful exploration and self-reflection. ${ }^{16}$

ICT is not only as the educational media in the world but also as the tool for people to develop their students' character. Utilizing ICT is not only developing students' motivation but also their characters. Students' character is very important for a country. Character is the foundation of the country. The country can advance if they have students with good characters. Technology offers new ways to contribute positively to character education. Because the education system is profoundly affected by new technologies, structural changes must be made to teach process skills as well as content knowledge to address the needs of the whole child.

The Character Education Partnership published Eleven Principles of Effective Character Education in 2007. Principle 1 notes that effective character education promotes core ethical values and supportive performance values as the foundation of good character. Character education holds that widely shared, pivotally important, core ethical values such as caring, honesty, fairness, responsibility and respect for self and others along with supportive performance values such as diligence, a strong work ethic and perseverance form the basis of good character\| Because character is a lens through which each individual views the world and makes decisions, character education and media literacy education work hand in hand. ${ }^{17}$

In Indonesia, ICT has grown rapidly in recent years. The development of cellular phones in households (RT) in Indonesia in the period 2006-2008 showed an increase. The ratio of RT to cellular telephone to all RTs in Indonesia increased from $24.60 \%$ in

\footnotetext{
${ }^{16}$ U. P. Network, Character Education: Creating a Framework for Excellence (Illinois: University of Illinois Extension Program, 2018), 4.

${ }^{17}$ T. Lickona, E. Schaps \& C. Lewis, CEP's Eleven Principles for Effective Character Education, 2007.
} 
2006 to $52.60 \%$ in 2008 . This also happened in all regions. The Kalimantan region is the region with the highest ratio since 2006 to 2008, followed by Sumatra and Java. ${ }^{18}$

The children must be protected from negative impact within Information Communication and Technology (ICT). So many services on ICT can be accessed by children to view the world. Therefore, the usage of ICT should be applied in education field. So, with the involvement of ICT in education will decrease of the bad effect on ICT. Further, ICT will assist the teacher becomes more competent and also confident in teaching. ${ }^{19}$ On the other word, teacher has crucial role to make sure that the usage of ICT will be useful to develop students' motivation more importantly their character.

This includes teaching students is to develop their awareness to behave in the right way in different social contexts. Almerico argues character education as an effort in teaching students about the important traits needed to achieve good character. ${ }^{20}$ As a result, students with good character must be applied in different social context. The Ministry of National Education realized 18 character of children based on pancasila, religion, goals, culture that should be maximized within education field as follows: (1) religious, (2) honest, (3) tolerant, (4) discipline, (5) hard-working, (6) creative, (7) independent, (8) democratic, (9) curious, (10) nationalistic, (11) loving, (12) respectful, (13) communicative, (14) peaceable, (15) fond of reading, (16) caring, (17) sociable, and (18) responsible. ${ }^{21}$ Then, to make sure the good character is achieved, there are the indicators of the success of character education deal with three aspects: cognitive, affective, psychomotor. ${ }^{22}$

Therefore, teaching does not only tell the students what is wrong and what is good. That is one of the reason the change of curriculum which more focus for shaping students' character. Having said aboved, ICT has a negative and also positive impact on students' mentality. by integrating ICT on education field will make students more

${ }^{18}$ K. Ramli, Komunikasi dan Informatika Indonesia, 2010. Retrieved August 13, 2018, from Kementerian Komunikasi dan Informatika: https://www.researchgate.net/publication/261367660 _Peran_Teknologi_Informasi_dan_Komunikasi_bagi_Bangsa_dan_Negara_Bagaimana_Sikap_Kita_seba gai_Murid_Kristus accessed

${ }^{19} \mathrm{G}$. Watson, Journal of Information Technology for Teacher Education, 2006. Retrieved August 13, 2018, from Griffth University: http://dx.doi.org/10.1080/1459399700200021

${ }^{20}$ G. M. Almerico, "Building Character Though Literacy with Childrens' Literature," Research in Higher Education Journal 26 (1): 2014

${ }^{21}$ Kementerian Pendidikan Nasional, Pedoman Pelaksanaan Pendidikan Karakter (Berdasarkan Pengalaman di Satuan Pendidikan Rintisan) (Jakarta: Balitbang Pusat Kurikulum dan Pembukuan, 2012).

${ }^{22}$ Nur Ainiyah, "Pembentukan Karakter Melalui Pendidikan Agama Islam," Jurnal Al-Ulum 13 (1) $2013: 25-38$. 
active and minimize and even eliminate the interest to abuse ICT.The advancement of information technology should be appreciated, but there are also a number of things to watch out for, including, the information presented on various internet pages, ranging from those that are very useful because they are relevant to the needs of downloaders, to the very detrimental because they do not match the level of development. child. Included in the type of information the latter is information that contains violent behavior, arbitrariness, other behavior that is not commendable and pornography. Therefore, the use of information technology in the education process needs to be accompanied by cultural and character education to prevent the negative impacts that can be caused.

Therefore, teacher in school is needed to prevent the abuse of ICT to educate the students about the usage of ICT. Chamorro and Rey as cited by Octavia et al (2018) revealed that the use of technology-based activities in the classroom is twofold: reinforcing already studied topics in class and promoting motivation. Accordingly, ICT seems meaningful in the classroom, yet how students behave towards ICT should be investigated further, especially their attitudes and expectations during the class. The roles of ICT in education.

Unfortunately, not only school has the responsibility of building students' character, but more importantly parents at home, have crucial role in controlling their children in using technology. Moreover, parents should monitor their children how their children use the technology, make sure that the features in their advices is still secure from the negative contents within its. Some parents also needed to be educated by the authority how ICT is really safe to be used by a child. Many parents less knowledge to keep their relationship with the children. Good communication is needed between parents and children, for making sure that the children have also good knowledge in using of ICT.

\section{E. The Relationship between Language Ethic toward Semantics and Pragmatics Study}

Students' language ethic has relationship to linguistics aspects, they are semantics and pragmatics. Semantic is a branch of linguistic which study about meaning about language itself. Semantics is defined as that part of linguistics that deals with 
meaning, word meaning and sentence meaning. Students' language ethic has relationship to linguistics aspects, they are semantics and pragmatics. Semanticsis the study of the " toolkit" for meaning:knowledge encoded in the vocabulary of the language and its patterns for building more elaborate meanings, up to the level of sentence meanings. ${ }^{23}$ Furthermore, pragmatic is a study about meaning of language based on the context. So, semantics and pragmatic are a different study eventhough both of them study about meaning.

Language ethic has direct relationship with semantics and pragmatics. It can be said that although this subjects learn about meaning, this subject also learn about stress and intonation, and dialect used when we are speak. In semantics study, student learns about spoken utterance that related to accent and intonation. Accents and intonation has relationship to language ethic directly.

A spoken utterance consists of more than words. In speech meanings are communicatednot merely by what is said but also by "the way it is said" that we called "Prosody". Prosody has two parts, accent and intonation. ${ }^{24}$

In semantic study, we must use different word, stress, and intonation if we write or speak something to other people. For example:

1. Can you switch on the blower? (for young people or partner)

2. Is possible for you sir, if you switch on the blower? Thank you (for older people)

In pragmatics study, the sentence 'It is very cold' by the speaker may mean that temperature is low (semantic approach), or some other explanation. A Pragmatic may also like to consider that may be the speaker wants to switch on the blower and used the statement "it is very cold" as an associated sentence. This sentence can be used if we are speak with our partner but if we are speak to older people is not polite, for example:

1. It is very cold? (for young people or partner)

2. I'm so sorry to say this sir, it is very cold? Do you feel it? Thank you (for older people)

\footnotetext{
${ }^{23}$ G. Patrick, An Introduction to English Semantics and Pragmatics (Edinburgh: Edinburgh Unversity Press, 2006).

${ }^{24}$ C. W. Kreider, Introduction English Semantics (New York: Routledge, 1998)
} 
Eka Apriani, Dadan Supardan, Eka Sartika, Suparjo, Ihsan Nul Hakim: Utilizing ICT to Develop Student's Language Ethic at Islamic University

\section{F. How can ICT develop students' character in semantic and pragmatics study?}

ICT can develop students' character in semantics and pragmatics study. Kinds of ICT that used by the teacher in teaching semantics and pragmatics study in university students were internet, laptop, PowerPoint, speaker, LCD, social media, etc. When the students learn that subject, they can learn about language ethic in semantics and pragmatic study. They can know about how to speak with other people politely.

Teacher can use internet as the references of semantics and pragmatic study when they teach students about language ethic content in that study. Teacher asks the students find out some material about how language used in semantics and pragmatics study. The students also learn about how language used can affect the meaning of word. Students can find out in internet about prosody (stress and intonation) when we are speak with other people, especially older people. Teacher can also use LCD, laptop, speaker, when they are taught semantics and pragmatics study in the classroom. This media can use to explain about language ethic. Thus media also use to demonstrate how language used in communication.

\section{G. Conclusion}

ICT plays important role in teaching and learning process. ICT is not only improves students achievement and motivation but also students' characters. One of the students' characters that influenced by Information, Communication, and Technology (ICT) is language ethic or politeness. Language ethic is the good attitude or moral when the people speak to other people, especially how the people used language to speak other people politely. Kinds of ICT that used by the teacher in teaching semantics and pragmatics study in university students were internet, laptop, PowerPoint, speaker, LCD, social media, etc. Hopely, this ICT can use by teacher in their classroom and also improve their students characters.

\section{H. References}

Kementerian Pendidikan Nasional, Sistem Pendidikan Nasional, Retrieved 08 Minggu, 2018, from http://kelembagaan.ristekdikti.go.id:http://kelembagaan.ristekdikti. go.id/wp-content/uploads/2016/08/UU_no_20_th_2003.pdf

Kementerian Pendidikan Nasional, Pengembangan Pendidikan Budaya dan Karakter Bangsa. (Jakarta: Badan Penelitian dan Pengembangan Pusat Kurikulum, 2010), 9 
Eka Apriani, Dadan Supardan, Eka Sartika, Suparjo, Ihsan Nul Hakim: Utilizing ICT to Develop Student's Language Ethic at Islamic University

Zubaedi. Desain Pendidikan Karakter Konsepsi dan Apliaksinya dalam Lembaga Pendidikan. Jakarta: Prenada Media Gorup, 2011.

Pantu, A. \& Luneto, H. "Pendidikan Karakter dan Bahasa." Al-Ulum 14 (01), 2014: 155.

Departemen Pendidikan Nasional. Standar Isi Kurikulum Mata Pelajaran Bahasa Indonesia. Jakarta: Depdiknas, 2006

Apriani, Eka. "A New Literacy: The Role of ICT to develop Student's Character." Ta'dib: Journal of Islamic Education 21 (1) 2016: 59.

Apriani, Eka. "The Misuse of ICT by Students: The Effect of Phornography and the Teacher Solutions." Tadrib: Jurnal Pendidikan Agama Islam, 2015: 1.

Tinio, L.V. ICT in Education. New York: Stephen Brwon Group, 2002.

Vrasidas, C. \& McIsaac, Integrating Technology in Teaching and Teacher Education, 2001. Retrieved August Monday, 13, from http://www.tandf.co.uk/journals

Alexander, N. C. Mar M. \& McCalman, D. "Information and Communication Technolgies (ICT): Components Dimensions and Its Ccorrelates." JITIM 24 (4) 2015.

Zuppo, C. M. "Defining ICT in a Boundaryless World: The Development of a Working Hierarchy." International Journal of Managing Information Technology 4 (3) 2012.

Diem, C. D. Perpustakaan, Kepustakaan dan Keaksaraan. Palembang: PT. Rambang, 2011.

Shihab, Quraisy. Tafsir Al-Mishbah: Pesan, Kesan dan Keserasian Al-Qur'an, Vol. 13. Jakarta: Lentera Hati, 2002.

Zuhriyah, Heni. Pendidikan Karakter (Studi Perbandingan Antara Konsep Koesoema dan Ibnu Miskawaih. Surabaya: IAIN Sunan Ampel, 2010

Kementerian Pendidikan dan Kebudayaan. Penguatan Pendidikan Karakter Jadi Pintu Masuk Pembenahan Pendidikan Nasional. Retrieved 08 Minggu, 2018, from www.kemdikbud.go.id: $\quad$ https://www.kemdikbud.go.id/main/blog/2017/07/ penguatan-pendidikan-karakter-jadi-pintu-masuk-pembenahan-pendidikannasional

Network, U. P. Character Education: Creating a Framework for Excellence. Illinois: University of Illinois Extension Program, 2018

Lickona, T. Schaps, E. \& Lewis, C. CEP's Eleven Principles for Effective Character Education, 2007.

Ramli, K. Komunikasi dan Informatika Indonesia. 2010. Retrieved August 13, 2018, from Kementerian Komunikasi dan Informatika: https://www.researchgate.net/publication/261367660

_Peran_Teknologi_Informasi_dan_Komunikasi_bagi_Bangsa_dan_Negara_Bag aimana_Sikap_Kita_sebagai_Murid_Kristus accessed

Watson, G. Journal of Information Technology for Teacher Education, 2006. Retrieved August 13, 2018, from Griffth University: http://dx.doi.org/10.1080/1459399700200021 
Eka Apriani, Dadan Supardan, Eka Sartika, Suparjo, Ihsan Nul Hakim: Utilizing ICT to Develop Student's Language Ethic at Islamic University

Almerico, G. M. "Building Character Though Literacy with Childrens' Literature." Research in Higher Education Journal 26 (1): 2014

Kementerian Pendidikan Nasional. Pedoman Pelaksanaan Pendidikan Karakter (Berdasarkan Pengalaman di Satuan Pendidikan Rintisan). Jakarta: Balitbang Pusat Kurikulum dan Pembukuan, 2012.

Ainiyah, Nur. "Pembentukan Karakter Melalui Pendidikan Agama Islam." Jurnal AlUlum 13 (1) 2013: 25-38.

Patrick, G. An Introduction to English Semantics and Pragmatics. Edinburgh: Edinburgh Unversity Press, 2006

Kreider, C. W. Introduction English Semantics. New York: Routledge, 1998. 